\title{
THE PEOPLE'S PRINCESS: VERNACULAR RELIGION AND POLITICS IN THE MOURNING FOR DIANA
}

\author{
Marion BOWMAN \\ Religious Studies Department, Faculty of Arts, The Open University \\ Walton Hall, Milton Keynes, MK7 6AA, United Kingdom
}

\begin{abstract}
The death of Diana, Princess of Wales, on August 31st 1997, led to extraordinary activity by millions of people as they reacted to the news in unexpected and seemingly unprecedented ways. Among the most fascinating phenomena were the many notes which were left for, about and to Diana, at the many 'shrines' which sprang up around Britain.

This paper will explore the multivalent nature of these notes - the extent to which they reflected folk belief about sainthood, heaven and divinity; the extent to which they were political comment veiled in the conventions of mourning; the extent to which they were either magnifications of common vernacular practice or a new development within it.

These remarkable documents were both personal and communal, public and private; it could be argued that they give a unique insight into popular religiosity in Britain at the turn of the Millennium.

Keywords: vernacular religion, death of Diana, Princess of Wales, folk belief about sainthood,
\end{abstract} letters to Diana

The scenes in Britain in the days after the death in a car accident of Diana, Princess of Wales, on 31 August 1997 were extraordinary. It was a 'liminal' period when republicans mourned a princess, royal behaviour was both criticised and dictated by the people, profane space was made sacred; and tradition was evoked, adapted and invented. The purpose of this paper is to explore the ways in which popular belief, practice and politics intermingled and found expression at this time, and to contextualise some of the religious and spiritual activity reported on and observed then.

Many magazine and newspaper columns, and numerous books, popular and scholarly, have been written on 'the Diana event'. However there was not one 'Diana event', there were many complex inter-related 'Diana events'. These Diana events were multivalent; they had different meanings for different people, both actors and observers. While it is not possible here to describe all the events in detail and review all the commentary, ${ }^{1}$ I want to draw attention to certain incidents to see what can be learned from them about popular politics, folk religion and contemporary spirituality in Britain.

${ }^{1}$ See WALTER, ed. (1999) for a broad-ranging collection of academic papers on the events following Diana's death. 


\section{THE PEOPLE'S PRINCESS}

Lady Diana Spencer, a descendant of the poet Edmund Spenser who wrote 'The Faerie Queen', had been the late twentieth century's fairytale princess - beautiful, kind and caring. As sociologist Tony WALTER points out, in an era of constitutional monarchy, 'every royal personage must appear both royal and yet ordinary, almost divine yet almost human' (WALTER 1999: 26). This Diana managed extremely well. Her glamour and beauty underlined her difference from the ordinary; her medical and marital problems stressed her humanity but endeared her to many; her perceived closeness to divinity was expressed in the readiness of mourners to declare her a saint or an angel on her death. In short, Diana 'out-royaled' the royals; she came to be thought of by many as the 'real' royal from whom other members of the Royal Family should learn. O'HEAR claims that what Diana stood for was 'the elevation of feeling, image and spontaneity over reason, reality and restraint' (The Week, 25/4/1998: 12).

The death of Diana was announced early on Sunday 31 August 1998. At breakfast time the recently elected Labour Prime Minister, Tony Blair, was interviewed. In this interview he used the phrase 'the people's Princess' which was to become an important motif throughout the Diana events.

At the time of the accident, which occurred in Paris, the Royal Family including the Queen, Prince Charles and the two young princes William and Harry were on holiday at Balmoral, the Royal Family's remote country estate in Scotland. There was therefore to some extent a lack of focus; Diana's body was in France, and the Royal Family were in Scotland. In the absence of personal contact, people turned to two empty buildings associated with and to some extent symbolising Diana and the Royal Family respectively, Kensington Palace and Buckingham Palace (see DAVIES 1999).

Among the most remarkable (and photogenic) scenes after Diana's death were the sheer numbers of flowers deposited in London outside Kensington Palace and Buckingham Palace, outside cathedrals and churches, and at war memorials and other public places throughout England. ${ }^{2}$ Messages and tributes to Diana, photographs of Diana, candles, balloons, toys and assorted personal belongings were also left at such sites. Books of Condolences appeared at Kensington Palace and Buckingham Palace, at civic buildings such as town halls, in cathedrals and churches, in Harrods (the prestigious London store owned by Mohammed Al Fayed, the father of Dodi Al Fayed who also died in the accident), in supermarkets and elsewhere. ${ }^{3}$ Technological innovation enabled 'virtual' books of condolences to proliferate on the Internet.

${ }^{2}$ I should make clear at the outset that I am a Scot (Scottish father, English mother) living in Bath, England; my personal experiences of and research into the Diana events were therefore based in England.

${ }^{3}$ One noticeable change of 'custom' in the aftermath of Diana's death seems to be the use of the book of condolence. When a young woman was murdered in the Bristol area, for example, a book of condolence was immediately set up in the Methodist church with which her family was connected. 
There were extraordinary scenes on the day of the funeral. Crowds lined the route of the funeral procession, many having spent the previous night on the pavement to ensure a prime position. The funeral service was broadcast to the masses outside the Abbey and an estimated audience of 31 million throughout the UK. After the service, people gathered to watch and throw flowers onto the car that transported Diana's body to her final resting place on an island in the grounds of her ancestral home.

\section{PEOPLE POWER}

It is important to remember that the Labour Party had fought an election in May 1997 against a Conservative government that had increasingly been seen as out of touch, hard-hearted and hypocritical. Much of the rhetoric of the election campaign had been phrased in terms of the 'the will of the people', the need for the 'voice of the people' to be heard, and the desire to create a more caring, inclusive society. After the election, Labour could present its victory as a victory of the people.

So, there was an awareness of and a taste for 'people power' in the summer of '97. And what happened was that 'the people', or to be more accurate, some people, those who became 'Diana's people' wanted to show respect and they wanted others to show respect too. Many have commented on the fact that there was a sort of coercion into a show of mourning more appropriate to the Victorian era than 1990's 'cool Britannia'. Britons who were not caught up in what was being portrayed as 'national grief' felt alienated and spoke of a 'fascism of grief', or 'the touchy-feely fascists'. Popular notions of appropriate behaviour in relation to the dead, to the Royal Family and to the nation were expressed and to some extent enforced. What happened was both an appeal to and revival of tradition, as well as the adaptation and in some cases the overturning of tradition.

\section{THE STATE OF THE NATION}

Another important aspect of the Labour victory was its election promise to pursue devolution for Scotland and Wales. Many, Labour supporters included, felt this might irreversibly change the nation and possibly lead to the break up of the United Kingdom as we know it. So we must also be aware that there was already an agenda of reflection on the nature of Britain and the state of the nation. Moreover, the changing face of Britain, which is now a multi-cultural and religiously plural society, was apparent in the Diana events. Messages and flowers were left and condolence books were signed by Britons of all descriptions. However, for all the newspaper talk of 'the nation united in grief', a number of events were curiously under-reported: the fact that many people, Muslim and non-Muslim, flocked to Dodi Al Fayed's grave; the fact that a London Muslim group distributed food to those camped outside Westminster Abbey on the night before the funeral; the fact that a multi-faith re- 


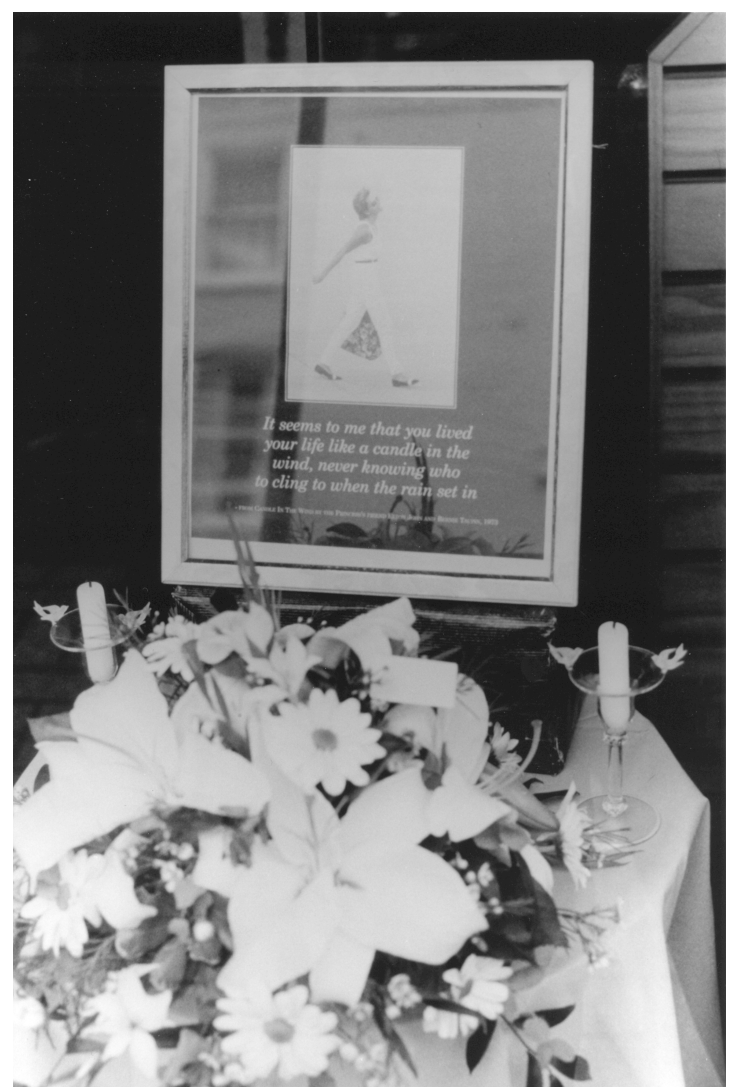

Fig. 1. Shop-window shrine in Bath

membrance service was held in Bradford. Different understandings of what constitutes 'the nation' were articulated (consciously or unconsciously) and although the language of inclusivity was often invoked this was not always demonstrated in the reporting. The title 'England's Rose' for Diana, for example, is demonstrative of that ambiguity; some would read there England meaning Britain, others would not!

\section{'THE ROYALS DIDN'T DESERVE YOU'}

Both the Royal Family and the capital city, London, are considered national symbols (I need hardly add that this is a particularly English perspective). The absence of the Royal Family from London, as they continued their holiday, became an increasing source of comment and criticism in the tabloid press that claimed to reflect the views of the people. Being out of London was equated with being out of touch with the people. 
At the heart of the matter was the fact that the Royal Family was seen to be behaving unlike the people. There was a great irony in the fact that whereas in the past the Royal Family, exemplified by Queen Victoria, had set the standards for elaborate mourning, the people were now dictating how the Royal Family should express their grief. The continued presence of the Royals at Balmoral and their apparent aloofness from the extraordinary scenes of public mourning became the focus of increasingly negative comment. Tabloid newspapers called on the Queen to come back to London to 'lead the nation's grief' and 'show us you care' (DAVIES 1999: 8). The Royal Family was being judged by the standards of the people, and also by the standards they felt had been set by Diana - the people's princess, the caring princess.

A variety of traditional methods were employed to show public disapproval of the Royal Family's behaviour in relation to Diana's death, and also of their treatment of her during her lifetime. There was the use of humour, as in the following examples:

Prince Charles was out walking the dog the other day. A passer-by said 'Morning', Prince Charles said 'No, just walking the dog. ${ }^{4}$

Why was Elton John invited to the funeral? So at least one old queen would be seen crying in public.

The messages with the flowers, though mainly expressing affection for Diana and sorrow over her death, were also used as vehicles for criticism of the Royal Family:

The Royals didn't deserve you. You showed the world what 'Royalty' is all about (MONGER and CHANDLER, 1998: 107).

While most messages were addressed to Diana, some were actually directed at the Queen: 'Why did you treat Diana so badly? You should be ashamed.' (MONGER and CHANDLER, 1998: 107).

A good example of 'people power' in relation to appropriate behaviour concerned the flying of the Royal Standard over Buckingham palace. It is the practice that the Royal Standard flies over Buckingham Palace when the monarch is in residence there; when the monarch is not there no flag is flown. At the time of a royal death, the Royal Standard still flies, as a sign of the continuity of the crown. Meanwhile, in ordinary society, it is common practice to fly a flag at half-mast as a sign of respect when any national figure dies or there is an occasion of local or national mourning. Thus, after Diana's death, what is considered Britain's national flag, the Union Jack, ${ }^{5}$ was flown at half-mast on public buildings - but not, of course, at Buckingham Palace. The absence of any flag on Buckingham Palace, and particu-

\footnotetext{
4 This is a play on the words 'morning' and 'mourning', which sound very similar. Wales.

5 It should be noted that the Union Jack contains symbols of England, Scotland and Ireland, but not
} 
larly the absence of the Union Jack at half-mast became the focus of increasing comment and irritation in the popular press. The explanation of the royal tradition concerning the Royal Standard was not deemed good enough. Ultimately, the people 'won'. On the day of the funeral, the Union Jack flew over Buckingham Palace at half-mast; the palace had to conform to the wishes of the people. Royal tradition was overthrown, and the people's view of appropriate behaviour was reinforced.

What some people did was to tap into the civil religious behaviour of what Anne Rоwвоттом (1998) calls 'the real royalists'. As Rоwвоттом has pointed out, when people flocked to London bearing gifts (primarily flowers but also photographs and other hand-made items), when they queued patiently, when they waited for hours to be in a good position to see the funeral procession pass, they were acting in the ways 'traditional' for civic visits by Royalty and other Royal occasions (some of the people who spent the night on the pavement in order to get a good view of the funeral procession had done the same for Diana's wedding 16 years earlier). The need to do something resulted in part in doing the done thing in relation to monarchy.

As Rоwвоттом has also pointed out, the study of civil religion and constitutional monarchy has been comparatively neglected, and many academics and journalists of republican persuasion tend to regard royalists as cranks and fanatics (this undoubtedly came through in the surprise and distaste expressed by some academics and journalists at the time). However, the confused and confusing nature of the relationship between the British and the monarchy (and perhaps particularly the English and the monarchy) needs further examination as it plays a vital role in Britain's 'folk politics' and notions of nationality.

\section{OFFICIAL AND FOLK RELIGION}

Religion and politics are interlinked in a situation where there is a state Church, with the monarch as its head. The Queen's role as Head of the Church of England came under some scrutiny in the light of some of the negative comments being made about the Royal Family's treatment of Diana. A message taped to the railings of Hyde Park read

'Dear Diana,

My dear you have been treated very badly by a family connected with my church' (MONGER and CHANDLER, 1998: 107).

One vicar wrote to Church Times, the newspaper of the Church of England:

Sir, - I suspect that I am not alone in being thoroughly ashamed that the name of the Princess of Wales was dropped from the State Prayers a year ago. Presumably it is too late for an apol- 
ogy to be made, but a lesson can be learnt: Lambeth should not automatically bow the knee to the commands of Buckingham Palace. (12/9/1997, No 7022:9).

The role of the Anglican churches and cathedrals in the aftermath of Diana's death and the fact that she was given "what was effectively a state funeral in the Church of England' (DAVIE and MARTIN, 1999: 188) highlighted the ambivalent relationship between the people and the state church at a time when Anglican church attendance in England is said to have fallen below 1 million on an average Sunday. One writer to the Church Times felt that the church could learn from Diana:

The Church is now at a crossroads: either she can become more isolated and out of touch with ordinary people, or she can take the message Princess Diana brought to the people, which is one of acceptance, love, forgiveness, and understanding.

The fact that many who do not usually attend church came to mourn and to worship this weekend shows that people still identify with the Anglican Church at such times. It is not too late for the Anglican Church to accept the people of this new generation gladly (12/9/1997, No 7022: 9).

If folk religion is 'the totality of all those views and practices of religion that exist among the people apart from and alongside the strictly theological and liturgical forms of the official religion' (YODER 1974: 14), there can be no doubt that folk religiosity was enacted and displayed in myriad forms after Diana's death. In a 1998 survey of Anglican clergy in Somerset, replies in answer to the question 'What aspects of Folk Religion do you encounter?' included 'Cult of Diana'. ${ }^{6}$ The messages left with the bunches of flowers tell us much about popular ideas of good and bad, of sainthood and of the afterlife. Many messages declared Diana instantly a 'saint' or an 'angel' and implied that she would continue to be in touch with people (particularly her sons) from beyond the grave. (It has been reported that one four year old whose mother died was told by his aunt that 'his mother has gone to Heaven to see Princess $\mathrm{Di}^{1} .^{7}$ ) There was also the assumption that Diana and Dodi Al Fayed would in some way be reunited: 'May you have as much fun in heaven as you did in St Tropez' (MONGER and CHANDLER 1998: 107). Though neither was overtly religious in conventional terms, it was assumed that both Diana and Dodi would find a place in Heaven, Diana because of her compassion and Dodi because he had made Diana happy.

\footnotetext{
${ }^{6}$ I am indebted to Geoffrey Walker, for this information, taken from his doctoral research on clergy attitudes.

${ }^{7}$ Personal communication from Gillian Bennett
} 


\section{SHOWING RESPECT}

While many commentators at the time stressed the uniqueness of the Diana events, scholars have pointed out comparisons such as the outpourings of public grief at the death of Queen Elizabeth I, Princess Charlotte (aged only 21 at her death in 1817), Queen Charlotte (the estranged wife of George IV) and Prince Albert (WOLFFE, 1999). Moreover, in the addition to the growth of roadside memorials in Britain, there had also been scenes of mass public mourning after such events as the Hillsborough tragedy and the King's Cross disaster, when public spaces had become communal sites of respect and remembrance (MONGER 1997). There was thus an historical tradition as well as a newly developing repertoire of how to behave in the face of tragedy, individual and communal, to draw on. Above all, two strong popular impulses emerged after the death of Diana - the need to do something and the desire to show respect.

Although the formal mourning dress and rituals of the Victorian era are long gone, folk ideas of appropriate behaviour in relation to death came to the fore. Some revived the largely defunct tradition of wearing a black armband. Many adapted this and reflected the recent use of the red ribbon loop to commemorate AIDS victims by wearing a loop of black ribbon. A particularly subtle show of respect was made by the proprietor of a rather elegant clothes shop in Bath, who for the day of the funeral changed her window display so that only black clothes were featured, in sharp contrast to the colourful, summery arrangement of the previous week. When 'proper' behaviour was neglected, 'the people' (i.e. Diana's people) were quick to admonish. In Bath, for example, there was criticism when blue pens were initially provided for people to sign the Condolence Book at the Guildhall. Black pens were deemed proper and were swiftly provided.

Many shops were closed on the day of the funeral, and notices appeared in their windows which were variations on the theme 'Out of respect for Diana Princess of Wales, this store will not open until $2.00 \mathrm{pm}$ on Saturday 6 September'. It was interesting that this was thought a fitting way of showing respect, in an age when older conventions of shop closure have increasingly been challenged by commercial pressures. This was commented upon by a cartoon in the satirical magazine Private Eye (12 September 1997) which featured two drawings of the same shop, the left-hand one with a sign in the window which read 'Closed out of respect for Princess Diana', the right-hand one bearing the sign 'Good Friday - Open as Usual'.

Many commentators remarked on how 'un-British' it all was. What clearly came as a surprise to many was the apparent outpouring of emotion from the nation that perfected 'the stiff upper lip'. However, although the media tended to concentrate on and project images of emotion, the overwhelming impression of many who were in the places where crowds gathered (such as Kensington Gardens) was of subdued quiet, calmness and respect. Indeed, Douglas DAVIES has pointed out that far from being un-British 


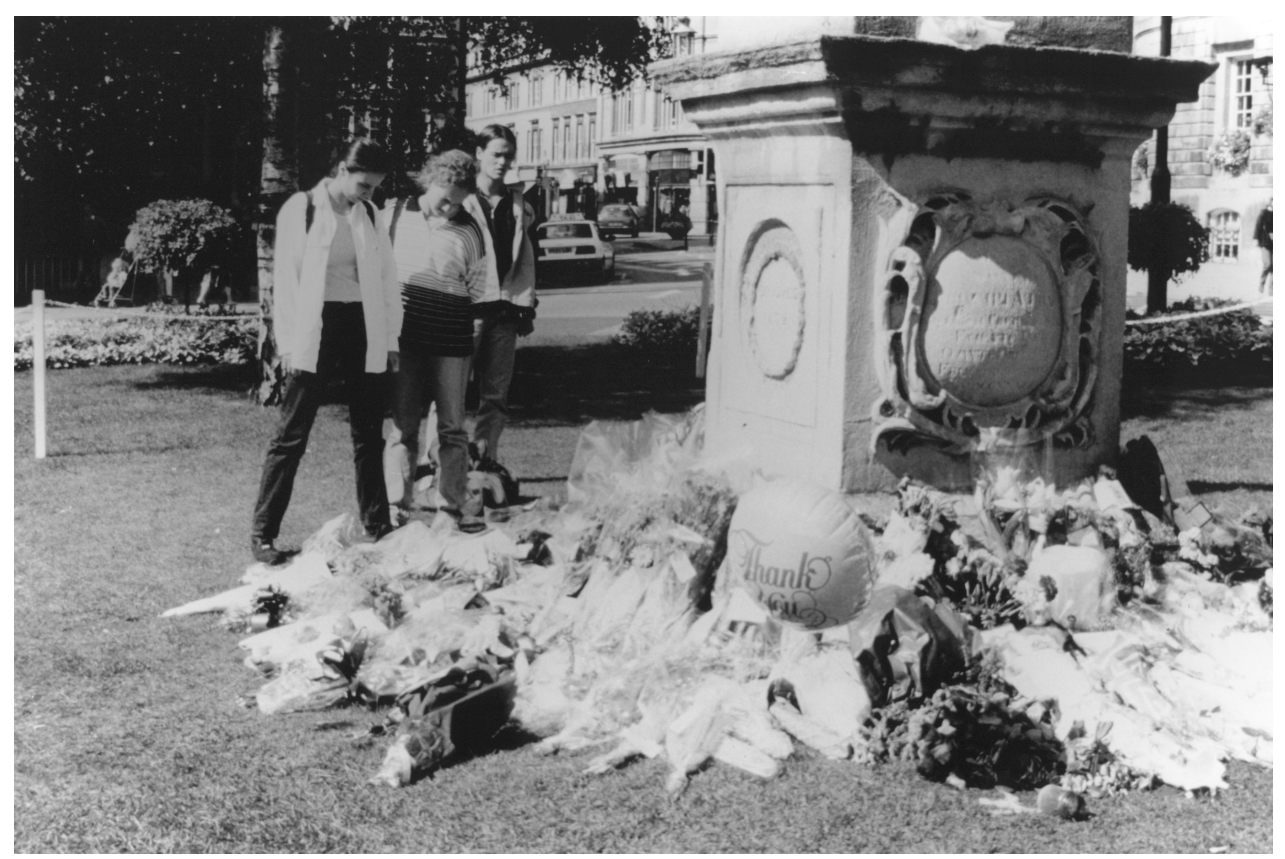

Fig. 2. Flowers and messages for Diana in Bath

The British habit of forming a queue ... came into its own as people made very long queues over many hours to sign books of remembrance. It was a kind of sacralizing of queuing (DAVIES, 1999:13).

\section{SHRINES}

One of the best demonstrations of continuity and change in relation to folk religion, I felt, was provided by the 'shop window shrines' (BOwMAN 1999). These were window displays that typically included a picture of Diana, flowers, candles or any combination thereof. In Bath, one upmarket shop had arranged a small table covered in a white cloth in its window in a shrine-like fashion. Raised up at the back of the table was a large frame containing a very informal photograph of Diana and below it printed in white on black the words from the Elton John song Candle in the Wind: 'It seems to me that you lived your life like a candle in the wind, never knowing who to cling to when the rain set in'. To the left and right in front of the frame were unlit white candles in elegant glass candlesticks with two tiny birds on the edge, and covering the table a large formal flower arrangement of white flowers and green foliage, white lilies predominating. (See illustration). Propped up in the window of a Bath cafe was the cover of a magazine, featuring a very happy, informal picture of 
Diana with her hands clasped as if in prayer, alongside which was a large blue glass jug of white and pale yellow flowers on the right, and a flowering pot plant on the left. A small city-centre flower shop window had a photograph of Diana wearing a tiara, placed between two formal white flower arrangements. There seemed to be some consensus about what flowers were most appropriate for such public display. One florist reported that several people had bought flowers to put in their shop windows:

"We've been selling a lot of white lilies," said Kit Pace, of Pulteney Bridge Flowers.

"Traditionally, lilies are a mourning flower that is associated with church" (Bath Chronicle 6/9/97: 15).

My local newsagent and video shop had in its window a glass vase of white lilies, with a lighted white candle to its right, and on the window a word processed 'poem' to/ about Diana. The manageress of the shop had come in at $5.00 \mathrm{am}$ on the day of the funeral to set up the arrangement, as a show of 'personal, private respect' from the staff who 'never had time to go off and say a prayer or sign a condolence book'. The manageress said 'We all wanted to do something. When someone dies, you want to show your sorrow in some ways, don't you?'. When I asked about the candle, she responded that everyone lights candles for someone who has died. As a florist's daughter, she knew that lilies were the 'right flower' but she also added that lilies are simple and uncomplicated and whatever people say about Diana 'she was a simple flower that blossomed into something fantastic'.

Among the most artistic of the shop window shrines was that of Jacaranda, a local flower shop. Soft white material was draped down and across the left side of the window and lined the base of the display. The centrepiece was a large glass vase of white lilies, and on the vase handwritten in capital letters, green ink on white A4 paper DIANA OUR THOUGHTS ARE WITH YOU. To the left of the central vase was another white urn shaped vase with small white flowers, in front some green foliage, to the right a small pot with a spray of white flowers, and behind that a tall green foliage plant in a pot. It looked as if considerable care and attention had gone into this display. The owner had done the display on the Sunday that Diana's death was announced. It was, he said, 'my tribute in my taste, my way of showing condolences'. He thought of the candle 'like you go into a church and put a candle for someone, it was like that.' People had come into Jacaranda and thanked him for doing the display.

The shrines for the most part appeared in shops that were privately owned and/ or small scale businesses. Those involved were able to do something publicly to express respect through the medium of their shop windows - although they all described their acts as 'personal' or 'private'. These shrines were created more formally than the outdoor shrines and tended to draw more on what was perceived as 'traditional', with for example the use of flowers and candles being self-conscious echoes of what would be expected in church. However, these shrines were not in 
church. Profane space - the shop window on the busy street - was transformed into sacred space, by the people, for the people, to show respect for the people's princess. $^{8}$

\section{VERNACULAR RELIGION AND CONTEMPORARY SPIRITUALITY}

While much of the Diana activity drew on traditional notions of appropriate and/or respectful behaviour, largely derived from Christian folk tradition, Britain's increasing religious pluralism and the growth of individualised spirituality needs to be taken into account. It is here perhaps more helpful to talk in terms of vernacular religion, defined by PRIMIANO as 'religion as it is lived: as human beings encounter, understand, interpret and practice it' (1995: 44). Away from the photogenic piles of flowers, there was a considerable amount of vernacular religiosity being articulated, at least some of which can be related to developments in contemporary spirituality in Britain which include the growth of pilgrimage, both the revival of old (pre-Christian and Celtic and/or medieval Christian) pilgrimages and the creation of new ones; the revival of customs, Christian and pagan (such as rag wells and well-dressing); the increasingly diverse use of what are regarded as sacred sites; the ritual creation of sacred space; a blurring of religious boundaries; and 'believing without belonging' (BOWMAN 1993, 2000).

I have already referred to the influence on the Diana events of conventional popular behaviour in relation to royalty, the growth of wayside shrines and the scenes of public mourning after the Hillsborough tragedy. However, much of the behaviour in connection with outdoor shrines was reminiscent of pilgrimage (CHANDLER, 1999), with prized possessions (e.g. a favourite record, items of clothing) being 'offered' to Diana. Notes were addressed directly to Diana, candles were lit, all-night vigils undertaken. As one reporter commented, 'It came as little surprise that some of those mourners, waiting through the night, believed they saw visions' (Country Life 11/9/1997, Vol CXCI, No 37: 82). There was undoubtedly a sense of 'liminality' and 'communitas', to use Victor Turner's terms, among mourners. Some of the shrines created around trees, with scarves and other items hanging from the branches were very reminiscent of rag wells, such as one recently 'revived' at Glastonbury (BOWMAN 2000). The 'collage' or 'mix and match' approach of contemporary spirituality was very much in evidence.

It is worth noting that while public space - such as Kensington Gardens - was converted to sacred space, large numbers of people flocked to the nation's cathedrals to light candles, regardless of denominational or religious affiliation. Religious buildings were taken over to some extent not just by laity, but by those whom the

\footnotetext{
${ }^{8}$ It should be noted that a shop window shrine appeared in the window of Harrods both immediately after the deaths of Diana and Dodi in 1997, and on the anniversary of their deaths in 1998.
} 
custodians would normally regard as non-believers. Although thousands of candles were lit at Wells Cathedral, for example, one cleric there felt that while the act of lighting a candle to some extent 'exorcised' or gave expression to people's grief, it frequently arose from a generalised sense of 'spirituality' which observably did not signal any renewed commitment to the church. People were often simply regarding the Cathedral as 'a place where the numinous or spirituality resides'. I was struck by that fact that two pagans of my acquaintance, women used to creating and officiating over their own rituals, felt it appropriate to go and light candles in Winchester Cathedral.

\section{PAGAN AND NEW AGE PERSPECTIVES}

There were distinctive perspectives on the Diana events in Pagan and New Age circles. One ingenious explanation of Diana's popularity, which both explained her appeal and the extent to which the Royal Family were out of touch and out of favour with the public was expounded to me by a Druid within 24 hours of Diana's death (Bowman 1998). He claimed that Diana Spencer was of the ancient British royal bloodline, and that her 'arranged marriage' to Prince Charles had been engineered to reintroduce this ancient bloodline and legitimise the House of Windsor. The British people had warmed to Diana so much because they instinctively recognised that she was truly royal, their 'real' monarch. He claimed that one reason that so much had been made of her touching people was that Diana had the gift of healing, the Royal Touch. ${ }^{9}$ Moreover, he pointed out that if Prince William christened William Arthur and born on the summer solstice, was to follow the ancient custom of the king using his second name, he would become King Arthur. Thus, through Diana, the ancient British royal bloodline would be restored to power, with a new King Arthur for the new millennium.

Just as many had identified with Diana through their own medical or marital experiences, an editorial in the Samhain 1997 issue of Pagan Dawn (the magazine of the Pagan Federation in Britain) referred to 'the way in which Diana was hounded and vilified by the media', adding

'As Pagans we have become used to seeing a similar denigration of Paganism in its many forms by contemptible editors who play with the public's fear of what they do not understand'. (No. 125: 3).

The editorial also said of Diana's death:

'It was an event which seemed to many of us to evoke some deeply buried spirit in the people of the United Kingdom, and per-

9 The 'Royal Touch' was the tradition that English and French monarchs were able to cure disease, particularly Scrofula, by touching the diseased person. 
haps even the world. ... As Pagans, many may see parallels with stories of the goddess Diana, or perhaps the Arthurian mythos.' (1997 No 125: 3).

Meanwhile, Kindred Spirit ('The UK's Leading Guide for Body Mind and Spirit') considered it 'fitting' to devote five pages of the Winter 1997/98 issue to readers' 'tributes to the People's Princess', 'especially as Diana was a strong proponent of complementary therapies' (41:53). One self-identified 'spiritual teacher' wrote

In recent weeks I have been privileged to experience what I feel may have been the most profound and significant event for humanity, and its future, in my lifetime.

The event was not, as most commentators believe, the death of Diana, but the incredible aftermath which captivated the world and brought us to what I believe is a new sense of understanding and awareness (41:53).

This writer explained how he and his wife had felt 'drawn' to go to the funeral, and to lay a floral tribute at Kensington Palace. As they mixed with the millions in London, there were

Peoples of all colours, races, ages and religions, united, possibly for the first time, by way of a feeling. This was not about Diana. People were grieving for what they felt they had lost within themselves: compassion, love and understanding for others (41:53).

The lowering of the Union Jack over Buckingham Palace was interpreted thus:

The monarchy, strong and immovable, had been moved: this silent peaceful revolution had started to demand and create the wishes of the whole, not the few (41:53).

The entire event was seen in terms of the ascent of humanity, 'laboriously moving through the charkas towards a spiritual union with the God-force, or 'Samadhi' (41: 54). Following the deaths of Diana and Mother Teresa, humanity shifted 'from the heart Chakra to the communication Chakra', 'verified' by Israel negotiating 'a more lasting peace in Lebanon' and Sinn Fein in Northern Ireland 'denouncing violence' and entering negotiations for an Irish solution (41: 54). The writer concluded

I believe the greatest gift that Diana left to us was to show us our potential to restore the universal understanding and compassion for each other that can unite our world in love not hate. If we can remember how incredibly powerful we all were, and how in a week, the world was changed forever, we may just have a chance (41:54). 
The 'folk political' events and the mourning following Diana's death were also analysed from a global, spiritual perspective by another Kindred Spirit reader:

If her death shakes the Royal Family into the modern age and they learn from her example and incorporate universal love, as well as service, into the way they live their lives, then surely this will be a wonderful legacy for the royal children ...

We can see how Diana's funeral helped many people on planet Earth to purge themselves of suppressed emotional wounds and this may be why they went 'overboard' with the floral tributes (41:57).

Drawing on the New Age rhetoric of karma, reincarnation and spiritual progression, this writer declared

I believe Diana was an old soul; she may well have elected to die when she did - at the height of her popularity and at a time of immense personal happiness - in order for her death to have the greatest impact on us.

I feel Diana's death signifies the Piscean Age rapidly coming to a close, for, as I see it, we took a quantum leap towards the Age of Aquarius when we mourned Diana's passing (41:57).

\section{CONCLUSION}

Two years after Diana's death, in August 1999, a number of newspapers were referring to Diana as the 'Forgotten Princess' and the lack of a permanent, public memorial seemed to reinforce this perception. The early euphoria of Labour's victory was perhaps wearing off and the people were possibly not feeling quite so powerful as they were in the heady days of the summer of '97. Devolution for Scotland and Wales had begun, and the future of the peace process in Ireland was uncertain.

Many of the issues raised and articulated around the death of Diana remain unresolved - the need for a more caring, inclusive society; the need for the Royal Family to both uphold and embody national tradition while remaining ready to change; the need for the British to address issues of national identity.

However, the public reaction to the death of Diana has taught us many things. As a former lecturer in a Study of Religions department that drew upon Ninian Smart's model of religion as a living organism of seven interacting dimensions (mythical, ritual, doctrinal, ethical, social, symbolic and experiential), for example, I found that the Diana events provided my students with a greater understanding of the dimensions, concrete means of articulating them from their own experience, and an appreciation of their complex inter-relationship. The Diana events also demonstrated the extent of religious pluralism in Britain, and the ways in which people who 
were superficially doing or observing the same things could have quite different interpretations of what was going on. Above all, the Diana events served as a timely reminder that while the British both retain a strong degree of vernacular and civic religious beliefs and practices, new spiritual ideas and expressions are moving from marginal to mainstream. The people know how to adapt, manipulate and create tradition in the realms of both folk religion and politics.

\section{LITERATURE}

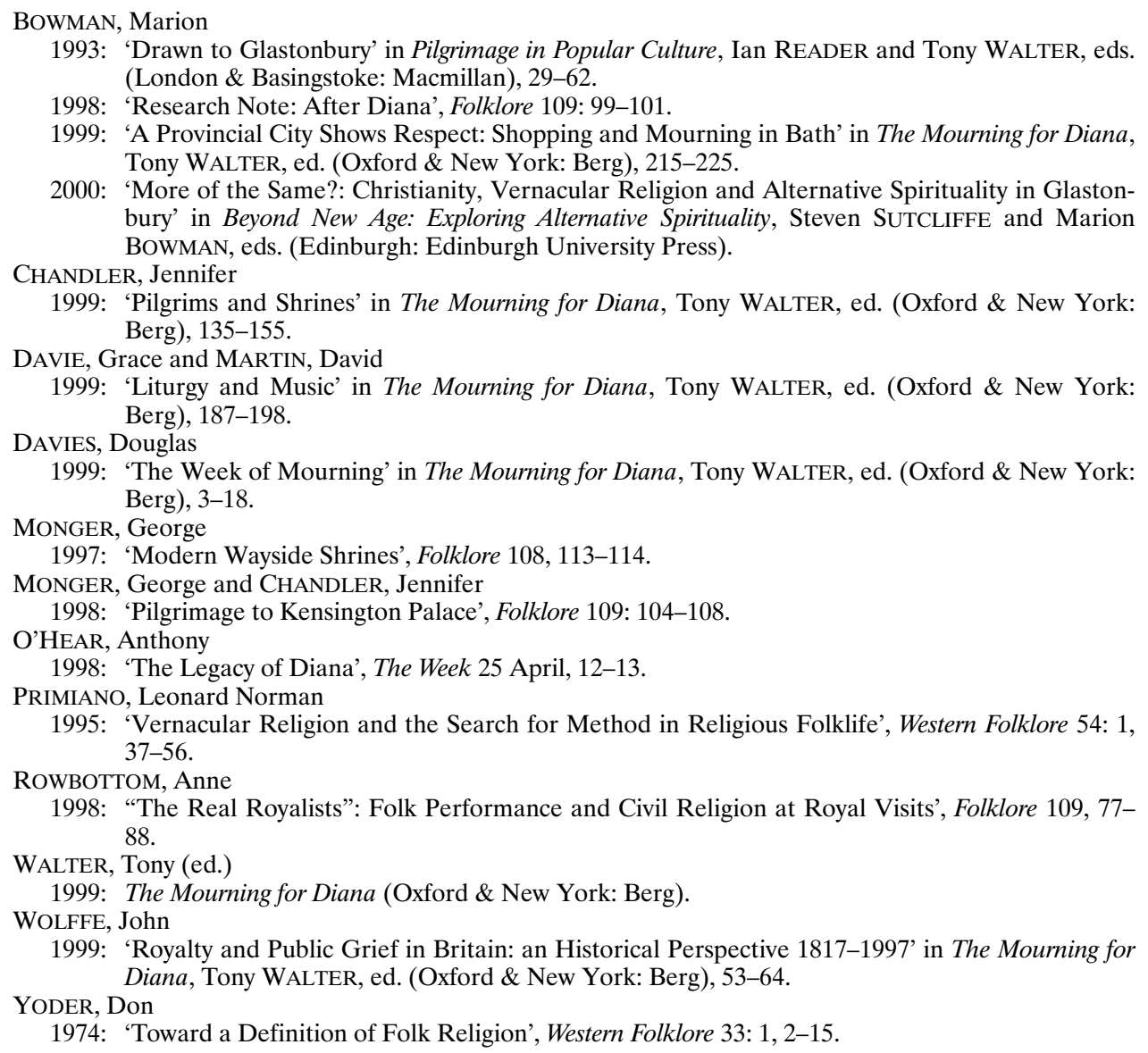

